\title{
Excessive Imbalances and Debt Crisis in the Eurozone
}

\author{
Juraj Sipko ${ }^{1}$ \\ ${ }^{1}$ Paneuropean University, Bratislava, Slovak Republic
}

\begin{abstract}
The main goal of the paper is to analyze the key factors that contributed to the macroeconomic imbalances and their impact on the debt crisis in the eurozone countries. Regression and correlation analysis indicated statistically significant relations between the key macroeconomic indicators, such as the current account, net international investment position, fiscal deficit and public debt. The paper found excessive imbalances within the eurozone countries. The study came to the conclusion that those countries that lost their competitiveness had external deficits, which caused fiscal deficits, and overall fiscal unsustainability. Therefore, to put the economy of eurozone countries on sustainable path a comprehensive reform agenda should be put in a place, mainly, medium-term fiscal consolidation plan, including structural reform in all eurozone countries.
\end{abstract}

Keywords: current account balance, public debt, sustainability, public finance

\section{Introduction}

The creation of European monetary union (EMU) was unprecedented step in the right direction in a modern economic history on the old continent. In line with the Maastricht Treaty, the Stability Growth Pact (SGP) was adopted for establishing the rules in maintaining public finance in sustainable level.

Despite the progress which has been made since the creation of the single currency, there are still some open questions concerning the degree to which the eurozone fulfils the main feature of the optimal currency area $[5,6]$.

Therefore, there is a need to analyze the key factors that significantly contributed to the present unsustainable level of public finance in some the eurozone countries.

\section{The past development of EMU}

Historically, before the establishing of the single currency macroeconomic development was relatively promising.

However, later on have been some trends of divergence. What is behind unsustainable development of EMU? What are the main factors which contributed to the deterioration of overall development in EMU? Which factors are behind the fiscal unsustainability - debt crisis, wide spread economic imbalances and vulnerability of some EMU member countries?

Therefore, the most important is to do a comprehensive analysis of the main macroeconomic indicators in the EMU.

\section{Latest economic development}

After the break up of the global financial crisis and global recession during the last three years the situation in EMU countries significantly deteriorated. They have been some trends instead of convergence.

The latest data clearly demonstrates that in the EMU countries continued the economic imbalances and eurozone is 
dealing with the vulnerability of the main macroeconomic indicators (Fig. 1).

This negative development caused the present debt crisis in the eurozone. At present, in the single currency area there are two groups of countries. First group of countries have reached the high level of competitiveness such as Finland, Germany and Netherlands. Second group of countries such as now well-know PIIGS countries that there are not able to compete in international market.

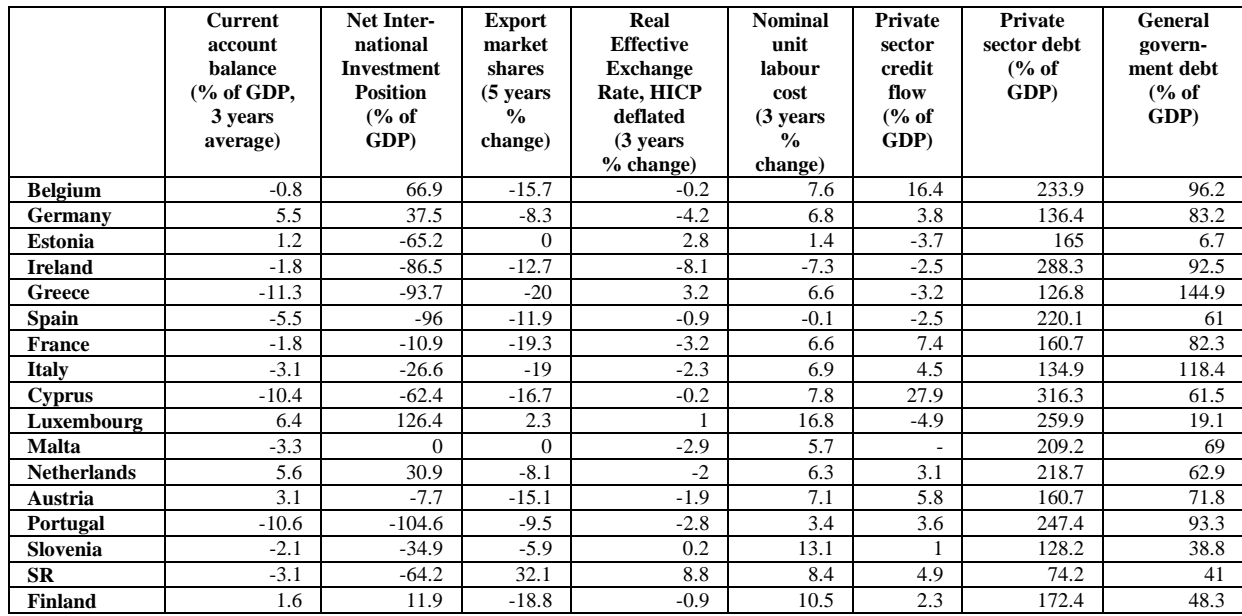

Fig. 1: Excessive imbalances within the eurozone (set from Eurostat, ECB, OECD data, 2011).

The countries with high productivity growth have reached high level of foreign exchange reserves, which significantly contributed to the Net Investment Position (NIP) see figure 2.

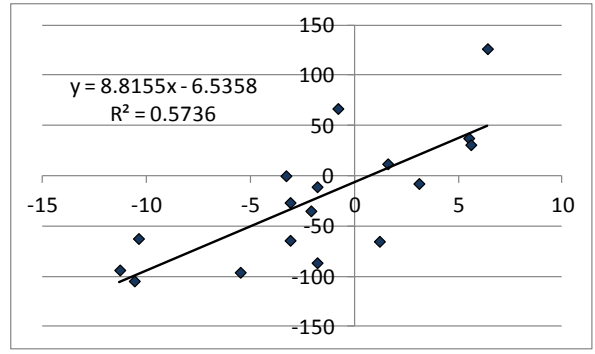

Fig. 2: Net Investment Position vs. Current account (2011).

Both the current account surplus and an export market share have positive impact on lowering the public debt.

The results of fitting a linear model to describe the positive linear relationship between the public debt and the current account balance of some selected countries are presented on fig. 3 .

Since the p-values, calculated in the ANOVA tables, are less than 0.05, therefore, there is a statistically significant relationship between the public debt and the current account balance at the $95.0 \%$ confidence level, including such counties as Denmark, Estonia, Greece, Ireland, Portugal, the Slovak Republic, Slovenia, Spain and as well in average in eurozone countries. The correlation coefficients from 0.7086 (Estonia) to 0.9692 (Spain) indicates a relatively strong linear relationship between the public debt and current account balance. However, that is the principally strongest positive correlation in the countries with the highest current account deficit.

However, the higher the value added of export, the higher current account surplus, 
the lower public debt as (see figure 3) in particular, in Germany (for linear relationship in the period of time 2006 2013 measured by correlation coefficient $\mathrm{r}=-0.7191 ; \mathrm{p}=0.0290)$, Austria $(\mathrm{r}=$ $0.7665 ; \mathrm{p}=0.0160$ ), and Finland (with the strongest negative correlation $\mathrm{r}=$ $0.9055, \mathrm{p}=0.0008)$.

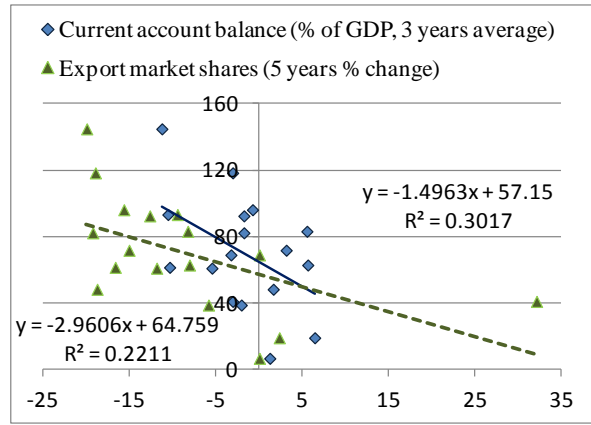

Fig. 3: Public debt vs. Current account and Export market shares

Loss of competitiveness always caused current account deficit and brought about reducing economic growth a deteriorated to the public finance. On one side those countries, which are in line with the world competition such as Finland, Germany, Luxembourg and Netherlands they have current account surplus, relatively very high net international investment position, stable labor costs, manageable public debt and relatively positive trends in reducing unemployment.

On the other side, such countries as present well-known as PIIGS, which they lost their competitiveness have current account deficit, negative net international investment position, loss market share, very high public debt and growing unemployment.

On the other side, countries such as Greece, Ireland, Italy, Portugal, and Spain with low level of structural reforms, very low productivity growth and with a relatively very low level of competitiveness have reached current account deficits.
Researchers, academia and policymakers generally agreed that the higher the current account deficit, the higher the public debt $[4,7]$. The critical for economic development is export performance.

On the other side, the majority of countries, including the most technologically developed countries as France, Germany, Netherlands and Finland, gradually declined their share in the international market of goods and services.

The main reason is slowly realized structural reforms, but also a significant factor is steadily growing economies of emerging markets; mainly, Southeast Asia. The most indebted countries have reached the most remarkable changes (e.g. Ireland, Greece, Spain).

By taking into consideration a threshold of $35 \%$ of GDP NIIP, there are two clear conclusions. First, those countries whose economies are export-driven, such as Germany, Netherlands, Finland and Luxembourg, have a very high proportion of these indicators.

Second, those countries that remarkably lost market share, including deterioration of competitiveness, have very low (negative) NIIP.

A majority of countries with very negative trend of NIIP such as Greece, Portugal and Spain also belong to the most indebted countries Lack of structural reforms and loss of competitiveness are the main factors that contributed to these negative trends in NIIP.

\section{Conclusion}

The creation of European Monetary Union was an unprecedented step in the right direction in a modern economic history. Pre-monetary union led to real convergence in some important indicators such as GDP, interest rates, net international investment position and current account. 
One lesson researchers, academia and policy-makers should learn is that loss of competitiveness always caused current account deficits and brought about a reduction in economic growth, which deteriorated public finance. On one side, those countries that are in line with world competition such as Finland, Germany, Luxembourg and Netherlands have current account surpluses, relatively very high net international investment positions, stable labor costs, manageable public debt and relatively positive trends in reducing unemployment.

On the other side, countries as present well-known as PIIGS that lost their competitiveness have current account deficits, negative net international investment positions, loss of market share, very high public debt and growing unemployment.

The global financial crisis and recession caused the debt crisis in European Union, but especially in some eurozone countries. Growing public debt in the euro area called for additional financing. Most debtor countries in the EMU lost access to the international capital markets.

High spreads for sovereign bonds and inability to get money on domestic and international capital markets raised a question of how to finance the public debt. The European sovereign debt crisis has not yet been fully resolved. Therefore, in this regard, in the euro area several crucial steps have been taken.

When EMU was created, the positive trends still appeared in some major macroeconomic indicators. However, one of the critical issues was loss of competitiveness that caused the external deficit which further was significantly correlated with public finance in some eurozone countries. Countries' loss of competiveness brought about lower economic growth and the decline in revenue of the general government budget. Official data analysis offers the clear conclusion that a majority of countries joining the EMU permanently broke down the basic rules in Stability and Growth Pact.

In addition, a majority of countries lost competitiveness and have reached deficits on current accounts, including lowering the net investment position. Excessive imbalances within the eurozone countries significantly contributed to the present fiscal unsustainably.

\section{References}

[1] http://epp.eurostat.ec.europa.eu/portal /page/portal/eurostat/home/

[2] http://www.ecb.int/home/html/index. en.html

[3] http://www.imf.org/external/index.ht $\mathrm{m}$

[4] Kumar, Manmohan S., Jaejoon Woo. "Public Debt and Growth". IMF Working Paper 10/174, 2010.

[5] Mundell, R. A "Theory of Optimum Currency Areas": American Economic Review, Vol. 51, 657-665, 1961.

[6] McKinnon, R. "Optimum Currency Areas": American Economic Review, Vol. 53, no. 3-5.pp. 717-725, 1963.

[7] Reinhart, Carmen M. This Time is Different Chartbook: Country Histories on Debt, Default, and Financial Crises. NBER Working Paper, February, 2010. 